\title{
Marketing Arrangements Used by Small Scale Bean Farmers in Kenya: What Needs to Change for Sustainable Trade Volumes?
}

\author{
Wanjala Simon P.O ${ }^{1 *}$, Karanja, David ${ }^{1}$, Wambua, Scholastica ${ }^{1}$, Otiep, George ${ }^{2}$, Odhiambo, \\ Collins $^{3}$ and Birachi, Eliud ${ }^{3}$ \\ ${ }^{1}$ Kenya Agricultural and Livestock Research Organization \\ ${ }^{2}$ Caritas Project, Catholic diocese of Homa Bay County \\ ${ }^{3}$ International Centre for Tropical Agriculture (CIAT), Nairobi \\ 1* Corresponding author: simon.omondi@kalro.org, Tel: +254 717444923 \\ Kenya Agricultural and Livestock Research Organization \\ P.O BOX 57811-00200, Nairobi, Kenya
}

\begin{abstract}
This case study assessed marketing arrangements used by small scale farmers in the Lake Basin and Lower Eastern bean corridors of Kenya to determine which markets work for rural producers and what changes are needed to produce and supply sufficient quantities for trade. Using exploratory research, data was collected through focus group discussions with six farmer groups representing a total of 1255 bean farmers and key informant interviews with extension staff.

The results indicated that $94 \%$ of the farmers produced beans before identifying buyers with only $6 \%$ participating in group marketing. Though spot-market transactions with brokers and traders provided ready cash for the farmers, formal buyers were perceived to be more reliable but difficult to find and, operated stringent requirements which were a barrier to entry. A theory of change to integrate smallholders into formal markets to sustainably produce and supply sufficient volumes for trade should entail a transformation agenda at four levels of the value chain: intensification of production through pure stand models with greater use of certified high yielding varieties; stable price guarantees; a market-driven research and extension service and; an enabling political, policy and business environment in the bean value chain. Further research is needed to pilot these changes in a case control study.
\end{abstract}

Key words: Small-scale bean farmers, marketing arrangements, formal and informal marketing, intensification models 


\section{Introduction}

Common bean (Phaseolus vulgaris L.) is a major staple food in Africa where it is recognized as the second most important source of human dietary protein and third most important source of calories of all agricultural commodities produced in the region [1,2]. It is the most important legume in Kenya, valued as a cheap source of protein especially for the low income population and consumer institutions such as schools, colleges, hospitals, prisons and food relief agencies [3]. Common bean is grown by more than three million households majority of whom are small-scale farmers in Kenya [4]. It has a short growth cycle which permits production when rainfall is erratic, provides food and income to the household before harvesting of other long season crops such as maize. It is cultivated twice a year in March to April and September to October at altitudes between 600-2000 meters above sea level.

Besides being a potential food insecurity and rural poverty exit strategy, common beans play an important role in the soil fertility enrichment through biological nitrogen fixation [4]. Rhizobium bacteria in bean nodules supply the plant with fixed nitrogen in form of ammonia and get carbohydrates in return. This presents another important cost-effective means of replenishing declining soil fertility in smallholder farms accelerated by inadequate use of inorganic fertilizers due to high costs.

About 3\% of the World's beans are produced in Kenya [5], mainly in the Lake Basin, parts of Rift Valley, Central highlands and Lower Eastern regions as intercrop by small scale farmers, majority being women [6]. Kenya has one of the highest consumption of beans in Africa which far exceeds supply and the deficit is supplemented through cross-border imports from Uganda, Tanzania, Rwanda, Eastern Democratic Republic of Congo and Ethiopia [7]. The country produces about 613000 MT against a demand of 748000 MT [3]. Despite the research efforts to enhance its productivity and clear benefits of common bean production for smallholders, its production remains low, despite the availability of several high yielding varieties with special attributes such as resistance to abiotic and biotic stresses, and market preferences released by research institutions (Table 1).

Table 1: Released dry bean varieties in Kenya developed by different institutions

\begin{tabular}{|c|c|c|c|c|c|c|}
\hline $\begin{array}{l}\text { Variety } \\
\text { name/code }\end{array}$ & $\begin{array}{l}\text { Year of } \\
\text { release }\end{array}$ & Owner(s) & $\begin{array}{l}\text { Optimal } \\
\text { production } \\
\text { altitude } \\
\text { range } \\
(\text { masl) }\end{array}$ & $\begin{array}{l}\text { Duration } \\
\text { to } \\
\text { maturity } \\
\text { (Months) }\end{array}$ & $\begin{array}{l}\text { Grain } \\
\text { yield } \\
\text { (t ha-1) }\end{array}$ & Special attributes \\
\hline Kat/Bean 1 & 1987 & KARI & $1000-1800$ & 2.5 & $1.2-1.5$ & $\begin{array}{l}\text { Drought tolerant, quick cooking, } \\
\text { no flatulence }\end{array}$ \\
\hline KK 8 & 1997 & KARI & $1500-1800$ & $2.5-3$ & $1.8-2$ & High yielding, Tolerant to root rot \\
\hline New Rose Coco & 2008 & $\begin{array}{l}\text { University } \\
\text { of } \\
\text { Nairobi }\end{array}$ & $1100-2000$ & $2.5-3$ & $\begin{array}{l}1.3- \\
2.3\end{array}$ & $\begin{array}{l}\text { Large grains, Moderate resistance } \\
\text { mosaic virus }\end{array}$ \\
\hline Miezi Mbili & 2008 & $\begin{array}{l}\text { University } \\
\text { of }\end{array}$ & $1000-2000$ & $2.5-3$ & $\begin{array}{ll}1.2- \\
2.26\end{array}$ & $\begin{array}{l}\text { Large grains, } \\
\text { Resistant to floury leaf }\end{array}$ \\
\hline
\end{tabular}




\begin{tabular}{|c|c|c|c|c|c|c|}
\hline \multirow{3}{*}{$\begin{array}{l}\text { Kenya Sugar } \\
\text { Bean }\end{array}$} & \multirow[b]{2}{*}{2008} & \multicolumn{2}{|l|}{ Nairobi } & \multicolumn{3}{|r|}{ spot, halo blight } \\
\hline & & University & $1000-1900$ & $2.5-3$ & $1.08-$ & Large grains, \\
\hline & & of & & & 1.81 & Resistance to common \\
\hline & & Nairobi & & & & bacterial blight \\
\hline Chelalang & 2008 & Egerton & $1800-2200$ & $2.5-3.5$ & $1.2-$ & High yielding \\
\hline & & University & & & 2.2 & \\
\hline Tasha & 2008 & $\begin{array}{l}\text { Egerton } \\
\text { University }\end{array}$ & $1500-2000$ & $2.5-3.5$ & $\begin{array}{l}1.1- \\
2.1\end{array}$ & High yielding \\
\hline $\begin{array}{l}\text { EMBEAN14 } \\
\text { (MWENDE) }\end{array}$ & 2014 & KARI & $1200-2400$ & 3 & 2.5 & $\begin{array}{l}\text { Tolerance to most fungal } \\
\text { diseases, Marketable seed type }\end{array}$ \\
\hline MN6 (Kenya & 2015 & $\begin{array}{l}\text { University } \\
\text { Of Nairobi }\end{array}$ & $\begin{array}{l}\text { Central, } \\
\text { Eestern }\end{array}$ & 3 & $1.1-2.8$ & $\begin{array}{l}\text { - Low flatulence; Biofortified } \\
\text { with Iron, zinc and Calcium }\end{array}$ \\
\hline Cheupe) & & & Eastern & & & \\
\hline Nyota & 2017 & KALRO & $\begin{array}{l}\text { 900-1800 } \\
\text { MSAL }\end{array}$ & $\begin{array}{c}65-70 \\
\text { days }\end{array}$ & $1.4-2.2$ & $\begin{array}{l}\text { Drought tolerant, Micronutrient } \\
\text { rich bean, Cooks fast }\end{array}$ \\
\hline Angaza & 2017 & KALRO & $\begin{array}{l}\text { 1200-1900 } \\
\text { MSAL }\end{array}$ & $\begin{array}{l}75-80 \\
\text { days }\end{array}$ & $1.4-2.5$ & $\begin{array}{l}\text { Sugar bean, cooks fast, } \\
\text { Micronutrient rich bean, Cooks } \\
\text { fast }\end{array}$ \\
\hline
\end{tabular}

\section{Source: http://www.kephis.org/images/VarietyList/april20170525.pdf}

Inadequate production of sufficient volumes for trade may partly be attributed to the widespread belief among farmers that bean markets are unreliable. A study by USAID [5] reported that farmer linkages to formal markets such as processors and institutional buyers in the country were very weak. In addition, data from market actors indicate that there is, in fact, significant unmet demand for common beans in Kenya. The deficit is expected to increase given the increasing population, rising costs of animal based proteins and health conscious consumers shifting to plant proteins. Studies done in the East African region indicate that beans are sourced from small scale farmers and marketed through long informal channels consisting of many intermediaries along the value chain [8-10]. These studies further indicate that although farmers determine the proportion of beans marketed, it is the traders who determine the prices offered.

\subsection{Overview of smallholder marketing arrangements}

There are mainly two types of marketing arrangements often cited in literature: Spot market transactions and collective action $[11,12]$

Spot market transactions: This is the informal marketing pathway consisting of many intermediaries and where local assemblers, brokers and traders are the main buyers of common beans from small scale farmers. It is the most important marketing channel for common beans in Eastern, Central and Southern Africa [13]. 
Collective action: In this arrangement, smallholders market farm produce through farmer organizations, contract farming or out grower schemes to formal institutions. It is a vertically coordinated chain relationship in which large buyers such as Cereal marketing Boards, Food processors, Wholesalers, Supermarkets, Schools, Hospitals, Exporters, Relief agencies enter into formal or informal agreement [12]. Cook and Chadad [14] observed that collective action among smallholder farmers can enhance agricultural production, bargaining power, reduction of transaction costs, formation of social capital, gender inequalities, provision of technical assistance and input services, acquisition of techno-managerial skills and advocacy. Nevertheless, several studies report that the challenges of operating agricultural enterprises in a highly dynamic and competitive global economic and technological environment have seen many farmer cooperatives or contract arrangements world-wide decline or exit due to free rider, portfolio, horizon, control and influence problems $[14,15]$. In Africa, contract farming for staples, especially cereals has had limited success [11, 16]. With Africa's population set to double to 2.5 billion by 2050 , the need to develop appropriate market linkages and models for smallholders as a pull factor for increased food production is urgent [17].

For the Kenyan case, given the national deficit and increasing demand on one side; and the seeming disconnect between farmers' perceptions of unreliable markets on the other, the objective of this study was twofold: First, to assess the type of marketing arrangement which work for small scale farmers and secondly, interventions needed to produce and supply sufficient volumes to the market, using a case study of the lake basin and lower Eastern bean corridors of Kenya.

\section{Methodology}

\subsection{Study Area}

The study was carried out in Homa Bay County in the Lake Basin and; Machakos and Makueni Counties in Lower Eastern Kenya between March and June 2017. The Lake Basin and Lower Eastern Kenya represent an important bean corridor in Kenya. Homa Bay lies between $0^{0} 15^{\prime} \mathrm{S}$ to $0^{0} 52^{\prime} \mathrm{S}$ and $34^{0} \mathrm{E}$ to $35^{\prime} \mathrm{E}$ at an altitude of 1240 metres and 1580 metres above sea level, while Machakos and Makueni lie between $0^{0} 31^{\prime} \mathrm{S}$ to $3.00^{\circ} \mathrm{S}$ and $36.45^{\circ}$ to $38^{0} 30 \mathrm{E}$. Rainfall in both regions is bimodal (March-May and September - November and ranges between $300 \mathrm{~mm}$ to 1300 mm annually. Homa Bay has $31000 \mathrm{Ha}$ under beans while both Machakos and Makueni have a combined area of 113,000 Ha under bean production [3].

\subsection{Study variables, data collection and analysis}

Data for this study was collected through a review of secondary information and interviews with key informants. Additionally, six focus group discussions (FGDs) representing a total of 1255 bean farmers, three FGDs from each region, were carried out with farmer groups to gain a deeper understanding of production characteristics and marketing arrangements; Strengths, Weaknesses, Opportunities, and Threats (SWOT) of the bean value chain; which marketing arrangements work for smallholder farmers; and what changes are needed to produce and supply sufficient volumes of beans to the market. Each FGD comprised 12 participants stratified in each group and randomly selected [18]. The participants per FGD were male, female and youth in the ratio of 5:5:2 
respectively. During discussions, participants talked among themselves on every key topic or question before a consensus was reached. They also ranked important issues through pair-wise ranking method [18]. All combinations were done and responses were recorded and visualized on flipcharts. Key informant interviews were also done with extension staff to triangulate information from FGDs. The exploratory research approach was more suitable for this study for identifying the real nature of the phenomenon under investigation in order to formulate relevant hypothesis for future empirical studies $[19,20]$. Data were analyzed using cross-case analysis by examining similarities and comparing incidents across groups.

\section{Results and Discussion}

\subsection{Formal and informal markets: which ones work for rural small holders?}

The results of focus group discussions identified and ranked two types of bean markets commonly used by farmers: Informal markets consisting of brokers, traders, individual consumers; and formal markets, mainly local schools, hospitals and food processors. Using the End Market analysis tool kit [21], from the parameters shown in Table 2, formal markets ranked much higher than informal markets in all the five variables. This result contrasts the existing practice and findings from a number of studies which show most of the beans in Kenya are marketed through informal channels [7, 9]. Additionally, the results in Table 3 suggest that farmers prefer informal marketing because market agents are readily available in the rural areas and more over it is a cash market. On the other hand, farmers reported that though formal markets are more reliable, they are difficult to find and operated rigorous standards which were a barrier to entry. Thus these findings seem to suggest that in small holder bean farming systems, informal markets seem to work for farmers despite their imperfections.

Table 2: Prioritization and ranking of bean markets

\begin{tabular}{lcc}
\hline Parameter & Informal Market & Formal Market \\
\hline Quantity & 2 & 3 \\
Quality & 0 & 5 \\
Price & 1 & 4 \\
Reliability & 1 & 4 \\
Availability of governance & & \\
structure & 0 & 5 \\
Total weight & 4 & 21 \\
Rank & 2 & 1 \\
\hline
\end{tabular}

Legend: weights $1=$ very low, $2=$ low, $3=$ average $4=$ high, $5=$ very high

Table 3: Reasons why farmers prefer marketing arrangement

\begin{tabular}{lll}
\hline Attribute & Informal marketing (brokers, retail traders) & Formal marketing (schools, hospitals) \\
\hline
\end{tabular}




\begin{tabular}{lll}
\hline Advantages & $\bullet$ Cash market & $\bullet$ Bulk purchase \\
& $\bullet$ Buyers readily available & $\bullet$ Bulk payment \\
& $\bullet$ Does not choose variety & $\bullet$ Reliable \\
& $\bullet$ Regular trading relationship & $\bullet$ Transparent weighting system \\
Disadvantages & $\bullet$ Own transport & \\
& - Price exploitation & - Delayed payment \\
& $\bullet$ Lack of standard measurement scale & $\bullet$ Difficult to find \\
& $\bullet$ Unreliable (spot market transaction) & $\bullet$ Weak relationship \\
\hline
\end{tabular}

Source: Focus group discussion and interviews

\subsection{Producing and supplying volumes for trade: what needs to change?}

With bean consumption trends estimated to be 748000 MT.700 000 MT per annum against a production of 613000 [3], there is urgent need for models that can sustain production and supply of sufficient quantities for trade. Results obtained in this case study suggest the following options:

\subsubsection{Intensification models}

The ranking of formal markets far above informal ones by farmers in this study calls for the need to re structure the bean value chain at four main nodes (Table 5) if sufficient volumes have to be produced and supplied to formal buyers comprising institutions, processors, retail supermarkets, exporters and importers. Smallholder farmers have been over studied in Sub Saharan Africa by different groups of actors including: knowledge institutions - universities and research, development agencies, NGOs and national agricultural investment plans. However, after decades of investments, there are indeed very few successful cases of commercialization in food staples among small scale farmers $[22,23]$. One of the reasons why small scale farmers have not taken off on a commercialization path is the lack of clear segmentation, targeting and positioning strategy to identify and work with a homogenous category. In this study three categories were evident: Subsistence-oriented bean farmers (19\%); Spot-market farmers who produce and only market when there is surplus (70\%), and a few market-oriented farmers $11 \%$ (Table 6). About $94 \%$ of the farmers grow beans before identifying a buyer. The multi objective nature of smallholder bean farming operating in a fast changing production, marketing and policy environments driven by forces of supply and demand, suggests markets that work for smallholders producing staple foods should have a dualistic marketing arrangement with greater integration in formal markets, while allowing participation to smaller extent in spot-market transactions which offer immediate cash important for smallholder household needs. There is therefore need to develop models to upgrade spot market farmers into market oriented producers and ultimately shareholders into value chains. AGRA report on the Status of Africa Agriculture argues that, "Agricultural assistance aimed at commercializing more small farms needs to be targeted to those farm households that have viable farm business prospects and capabilities. Alternative types of assistance should be given to other types of small households if resources are not to be wasted, or farm household misled into unsustainable livelihood strategies" [17]. Commercialization and globalization of agriculture has opened opportunities to supply products to markets. However, access to these markets has stringent requirements which rural producers must re organize to comply [24].

To integrate rural smallholders into formal markets, the production stage of the chain must be transformed into a market-facing entity that guarantees quantity, quality, safety, reliability, 
traceability, and governance structures demanded by these markets. Production needs to change from current practice where most farmers allocate less than one acre to bean production usually intercropped, to intensification through pure stand models (Table 6), with increased use of improved technologies [25]. From using grain, to using certified seeds and growing high yielding varieties demanded by the market (Tables 1,2 and 5); from growing beans before identifying buyers (Table 6) to producing for specific buyers; from individual marketing (Table 7) to collective marketing through village aggregation centres; from spot-market transactions to contract farming. Advantages and benefits of contract farming for smallholders have been demonstrated in several studies including Poole and Freece [11], Costales and Catelo [26] and Prowse [27].

To put smallholder bean farmers on a commercialization path, all the weaknesses identified in the SWOT matrix (Table 4) can be turned into strengths to take advantage of the growing demand.

Thus a theory of change [28] focusing on transforming common bean production into a commercial enterprise linked to large national buyers and export markets is key to increasing volumes for trade, and can help reduce reliance on imports to meet the growing demand in Kenya.

Table 4: SWOT of bean value chain

\begin{tabular}{|c|c|}
\hline Strengths & Opportunities \\
\hline $\begin{array}{l}\text { - Many bean farmers } \\
\text { - Soils appropriate for bean production } \\
\text { - Individual land ownership } \\
\text { Weaknesses } \\
\text { - Use of grain of different varieties as seed } \\
\text { - Lack of knowledge on varieties demanded by } \\
\text { - } \text { Lack of collective marketing } \\
\text { - Lack aggregation centres } \\
\text { - Brokers and middlemen determine price } \\
\text { - Inadequate agronomic practices } \\
\text { - Inadequate financial capital for inputs } \\
\text { - Weak policy / political environment for bean } \\
\text { - } \text { production and commercialization } \\
\text { Weak horizontal and vertical linkages among }\end{array}$ & 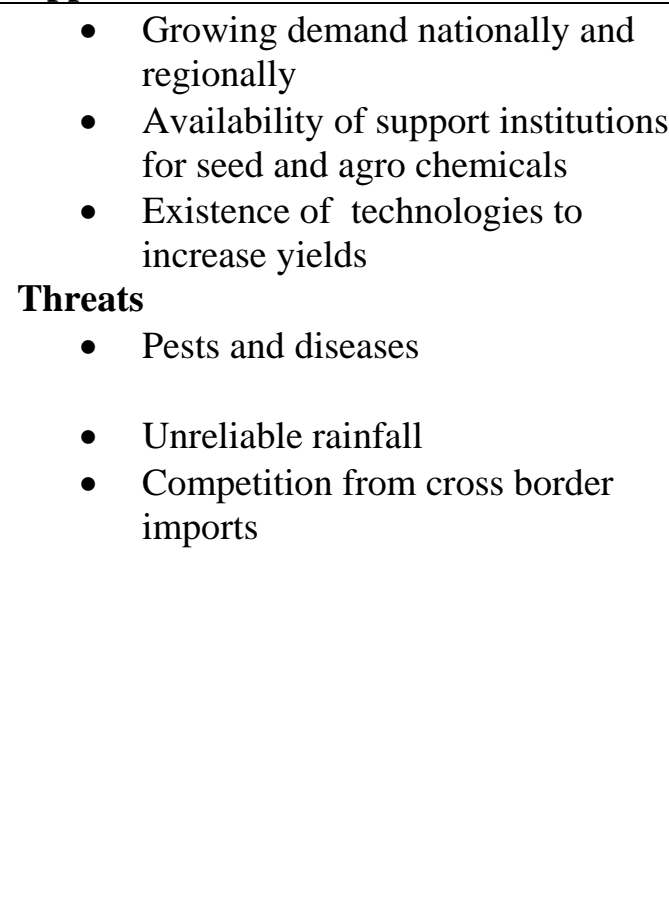 \\
\hline
\end{tabular}

Table 5: Farmer perceptions on changes needed for producing and supplying volumes to the market 


\begin{tabular}{llll}
\hline Small scale farmers & $\begin{array}{l}\text { Service } \\
\text { Institutions }\end{array}$ & Buyers & Policy \\
\hline $\begin{array}{l}\text { Group production and } \\
\text { marketing }\end{array}$ & $\begin{array}{l}\text { Dissemination of } \\
\text { varieties demanded } \\
\text { by market }\end{array}$ & $\begin{array}{l}\text { Reliable institutional } \\
\text { buyers (supermarkets, } \\
\text { processors, exporters, } \\
\text { Food agencies, schools) }\end{array}$ & $\begin{array}{l}\text { National and County } \\
\text { government support and } \\
\text { Promotion of bean production } \\
\text { and trade for incomes, food } \\
\text { and nutritional security }\end{array}$ \\
$\begin{array}{l}\text { Increased acre rage } \\
\text { under beans }\end{array}$ & $\begin{array}{l}\text { Technical advice } \\
\text { and training of } \\
\text { farmers on GAP } \\
\text { Avail credit for } \\
\text { farm priority inputs }\end{array}$ & $\begin{array}{l}\text { Contractual } \\
\text { engagement }\end{array}$ & \\
$\begin{array}{l}\text { Grow common } \\
\text { variety }\end{array}$ & & & \\
$\begin{array}{l}\text { Contract farming } \\
\text { Common aggregation }\end{array}$ & & & \\
\hline
\end{tabular}

Source: Focus group discussion and interviews

Table 6: Production characteristics

\begin{tabular}{|c|c|c|c|c|c|c|c|c|}
\hline \multirow{4}{*}{ Parameter } & \multirow{4}{*}{$\begin{array}{l}\text { Region } \\
\text { County }\end{array}$} & \multirow{2}{*}{\multicolumn{2}{|c|}{$\begin{array}{r}\text { Lake Basin } \\
\text { Homa Bay }\end{array}$}} & \multicolumn{5}{|c|}{ Lower Eastern } \\
\hline & & & & & \multicolumn{2}{|c|}{ Makueni } & \multicolumn{2}{|l|}{ Machakos } \\
\hline & & Rangwe & Wiga & Ndhiwa & Kima Kiu & Kasikeu & Mua & Overall \\
\hline & & $\begin{array}{l}\% \\
(\mathrm{~N}=125)\end{array}$ & $\begin{array}{l}\%(\mathrm{~N}= \\
275)\end{array}$ & $\%(\mathrm{~N}=55)$ & $\begin{array}{l}\% \\
(\mathrm{~N}=300)\end{array}$ & $\begin{array}{l}\% \\
(\mathrm{~N}=200)\end{array}$ & $\begin{array}{l}\% \\
(\mathrm{~N}=300)\end{array}$ & $\begin{array}{l}\%(\mathrm{~N}= \\
1255)\end{array}$ \\
\hline \multirow{3}{*}{$\begin{array}{l}\text { Land allocated } \\
\text { for bean } \\
\text { production } \\
\text { (acres) }\end{array}$} & $<0.5$ & 60 & 15 & 40 & 5 & 0 & 10 & 22 \\
\hline & $0.5-1$ & 30 & 54 & 60 & 15 & 50 & 80 & 48 \\
\hline & $>1$ & 10 & 31 & 0 & 80 & 50 & 10 & 30 \\
\hline \multirow{2}{*}{$\begin{array}{l}\text { Production } \\
\text { system }\end{array}$} & Intercrop & 90 & 77 & 100 & 30 & 30 & 15 & 57 \\
\hline & Pure stand & 10 & 23 & 0 & 70 & 70 & 85 & 43 \\
\hline \multirow[t]{2}{*}{ Yield } & $\begin{array}{l}\text { Average yield per } \\
\text { acre (Intercrop) }\end{array}$ & 2.5 & 2.5 & 3 & 3 & 3 & 2.5 & 2.75 \\
\hline & Pure stand & - & - & - & 7 & 6 & 4 & 5.5 \\
\hline \multirow{3}{*}{$\begin{array}{l}\text { Objective for } \\
\text { bean farming }\end{array}$} & Subsistence only & 19.5 & 15 & 60 & 20 & 0 & 0 & 19 \\
\hline & $\begin{array}{l}\text { Subsistence }+ \text { surplus } \\
\text { marketing }\end{array}$ & 80 & 85 & 40 & 75 & 42 & 100 & 70 \\
\hline & Marketing & 0.5 & 0 & 0 & 5 & 58 & 0 & 11 \\
\hline \multirow{2}{*}{$\begin{array}{l}\text { Proportion of } \\
\text { farmers growing } \\
\text { beans }\end{array}$} & $\begin{array}{l}\text { After identifying } \\
\text { buyer }\end{array}$ & 10 & 10 & 0 & 10 & 5 & 0 & 6 \\
\hline & $\begin{array}{l}\text { Before identifying } \\
\text { buyer }\end{array}$ & 90 & 90 & 100 & 90 & 95 & 100 & 94 \\
\hline
\end{tabular}

Table 7: Marketing arrangements 


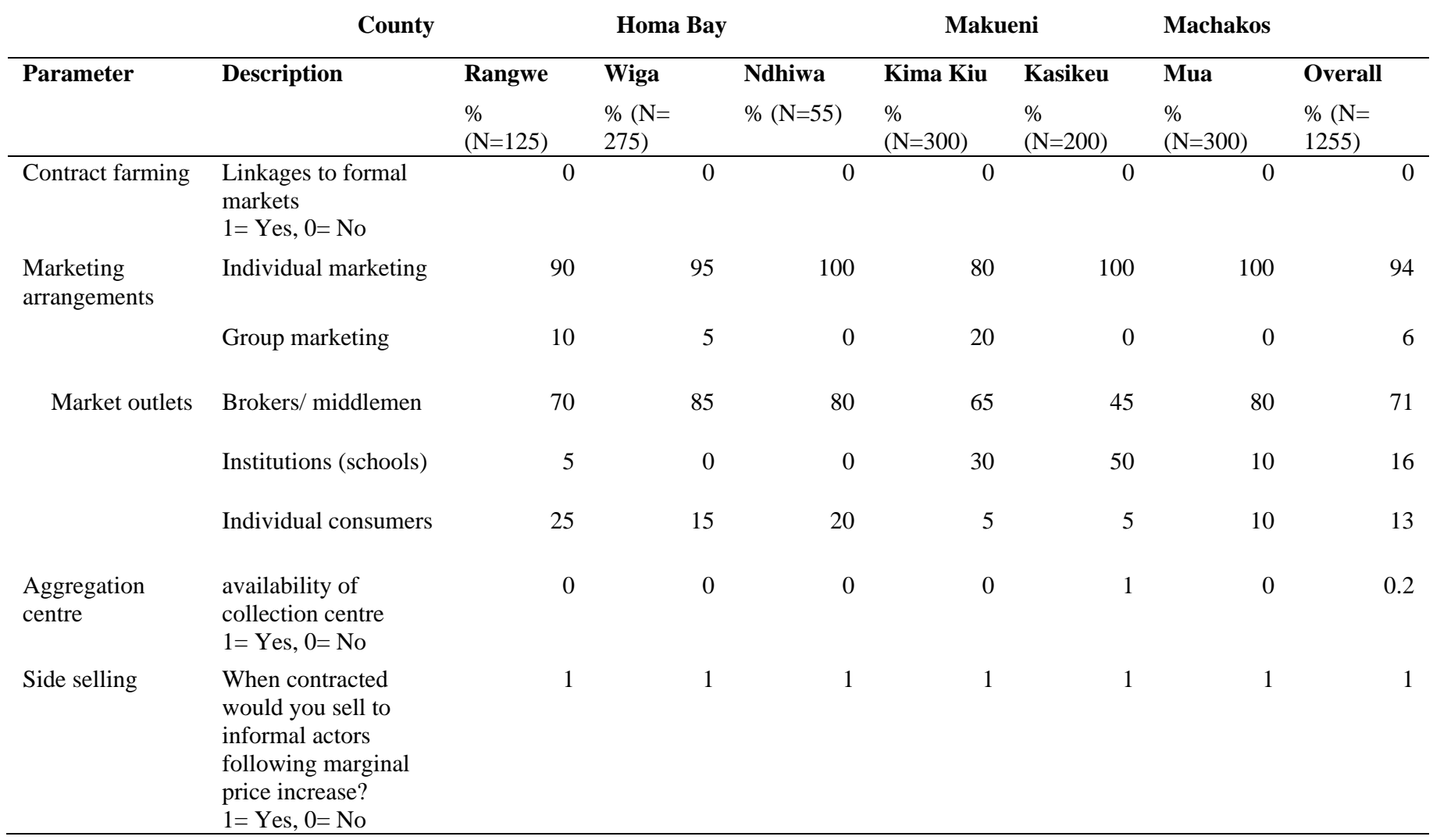

\subsubsection{Market actors: Reliability and Price guarantees}

Interviews with farmers and extension agents revealed that perhaps the biggest challenge faced by farmers producing for formal buyers pertains to difficulties in finding these markets, delayed payments, weak relationships and compliance with high quality standards or even arbitrarily raising standards to reduce intake (Table 3). On the other hand, smallholders easily break contracts with formal markets through side selling whenever there is a marginal increase in prices occasioned by forces of supply and demand (Table 7). Building mutual trust is essential in fostering long term trading relationships. To ensure a win-win situation, reliability and stable price guarantees should be the key features of negotiated agreements with formal buyers. Establishing a strong market institution with double-facing back ward linkages to provide farm supply services and; forward linkages responding to consumer needs for quality, safety, product diversity and affordability will make formal buyers attractive to rural smallholder bean producers. Poku et al [12] and Barrett [29] in their review of case studies in Sub Saharan Africa also suggest that contracts with embedded support services are essential in fostering smallholder market participation and the long-term sustainability of trading relationships. 
Farmers and extension agents identified three institutional issues necessary to support bean productivity and market orientation. These are: dissemination of bean varieties demanded by the market, technical advice on Good Agricultural Practices (GAP) and credit for priority inputs (Table 5). The first two issues relate to research and extension services, which are public good aimed at improving the agricultural sector. Institutional failure still limits access to the much needed productivity enhancing services. However, liberalization policies which swept much of Africa in the 1990s ought not to be an excuse for institutional voids [30]. In Kenya, the national and county governments which are responsible for policy and implementation of agricultural programmes should re structure research and extension into modern, market-driven, globally competitive institutions that respond to the technological needs of smallholder farmers' quest to access formal markets.

Access to credit for farm priority inputs is another area worth special focus. From the interviews, financing is needed by bean farmers to support land preparation and expansion and purchase of seed and fertilizer. With linkages to formal markets, these costs could be recovered from farm sales through interlocked financing arrangements with credit institutions [31.

\subsubsection{Political, policy and business enabling environment}

Although bean production has a multiplier effect on the socio-economic well-being of rural producers, consumers, and the national economy, it has not received sufficient policy attention compared to other staple foods such as maize. Neither is there significant investment by commercial seed companies. In pursuit of the national development goals [32] and key Sustainable Development Goals [33] which are anchored on food and nutritional security, employment and incomes, empowerment of women and youth, promotion of sustainable agriculture and building partnerships; an enabling policy and business environment for bean production and trade should be promoted. An affirmative action that compels learning institutions to accept beans in lieu of cash for school fees as is the case in Zimbabwe, in addition to preferential government tenders; Aid agencies and food manufacturers actively purchasing beans directly from farmer organizations would have great impact on rural economic development. Indeed, the Africa Agriculture Status Report (AGRA, 2017) acknowledges that an inclusive agricultural agenda requires that governments support and guide the transformation through a stable and enabling economic and policy environment, adequate rural infrastructure, investment in agricultural research and development. Governments must also work with the private sector and non-governmental organizations (NGOs) in undertaking targeted interventions to help commercialize many more smallholders, and assist the development of Small and Medium Enterprises along value chains.

Thus the changes outlined in this study could be useful in supporting smallholder bean farmers produce volumes for trade. The agenda for further research should entail piloting these changes in a case control study.

\section{Conclusions}

This study sought to assess which marketing arrangements work for rural smallholder farmers in the bean corridors of the Lake Basin and Lower Eastern Kenya. The findings reveal that though spot-market transactions with brokers and traders provided ready cash for the farmers, formal buyers were more reliable but difficult to find and had rigorous requirements. The multi objective nature of smallholder bean farming operating in a fast changing production, marketing and policy 
environments driven by forces of supply and demand, suggests markets that work for smallholders producing staple foods should have a dualistic marketing arrangement with greater integration in formal markets, while allowing participation to smaller extent in spot-market transactions which offer immediate cash important for smallholder household needs.

A theory of change to integrate smallholders into formal markets to sustainably produce and supply sufficient volumes for trade, should entail a transformation agenda at four levels of the value chain. First, intensification of production through pure stand models; secondly, Stable price guarantees; Third, a market- driven research and extension service and; lastly, an enabling political, policy and business environment in the bean value chain. Further research should entail piloting these changes in a case control study.

\section{Acknowledgement}

The authors are grateful for the support given by farmer organizations in the Lake Basin and Lower Eastern Kenya, and extension staff in the region. The study was facilitated by Kenya Agricultural and Livestock Research Organization and funded by International Development Research Centre (IDRC) and Australia Centre for International Agricultural Research (ACIAR) Pre Cooked Bean Project.

Author Contributions: W.S.P.O and K.D conceived and designed the study; W.S.P.O., K.D., W.S., O.G. and O.C participated in data collection and analysis; W.S.P.O, K.D and B.E. wrote the manuscript.

\section{Conflicts of interest}

The authors declare no conflict of interest.

\section{References}

1. Birachi, E. A.; Ochieng, J.; Wozemba, D.; Ruraduma, C.; Niyuhire, M. C.; Ochieng, D. Factors Influencing Smallholder Farmers' Bean Production and Supply to Market in Burundi. Afr Crop Sci J 2011, 19(4), 335-342.

2. Buruchara, R.; Chirwa, R.; Sperling, L.; Mukankusi, C.; Rubyogo, J. C.; Muthoni, R.; Abang, M. M. Development and Delivery of Bean Varieties in Africa: The Pan- Africa Bean Research Alliance (Pabra). Model. Afr Crop Sci J. 2011, 19(4), 227-245.

3. Government of Kenya. Economic review of Agriculture. Ministry of Agriculture. 2013.

4. Katungi, E.; Farrow A.; Chianu, J.; Sperling, L.; Beebe, S. Common bean in Eastern and Southern Africa: a situation and outlook analysis. International Centre for Tropical Agriculture. 2009.

5. United States Agency for International Development. Staple Foods Value Chain Analysis. Country Report -Kenya. Chemonics international. 2010.

6. Wortmann, C.S.; Kirby, R.A.; Eledu, C.K.A.; Allen, D.J. Atlas of Common Bean (Phaseolus vulgaris L.) Production in Africa. CIAT, Cali, Colombia (Publication No. 297.1998.

7. Mauyo L.W.; Chanu J.N.; Nassiuma, B.K.; Musebe, R.O. Cross-Border bean market performance in Western Kenya and Eastern Uganda. JSSM, 2010.doi:10.4236/jssm.2010.34057. 2010. 
8. Ouedraugo, I.; Kere, P.; Osore, J.; Matheka, F.; Holtzman, J.; steffen, P. Dry Beans Sub Sector in Kenya. A rapid Appraisal with Emphasis on Market Information Needs and Extension Issues. 1994.

9. Kibiego, M.B.; Odhiambo, M.O.; Kimani, P.M. Analysis of bean marketing system in urban areas of Kenya. African Crop Science proceedings, 2003, Vol 6, 587-590. Africa Crop Science Society.

10. Korir, M. Cross-Border bean marketing between Northern Tanzania and Nairobi, Kenya. M Phil. Thesis, Moi University. 2005.

11. Poole, N.; Freece, A. A Review of Existing Organisational Forms of Smallholder Farmers' Associations and their Contractual Relationships with other Market Participants in the East and Southern African ACP Region. Food and Agriculture Organization of the United Nations (FAO). AAACP Paper Series - No. 11. 2010.

12. Poku, A.; Birner, R.; Gupta, S. Making Contract Farming Arrangements Work in Africa's Bioeconomy: Evidence from Cassava Outgrower Schemes in Ghana, Sustainability, 2018, 10, 1604

13. Sichilima1, T.; Mapemba, L.; Tembo, G. Drivers of Dry Common Beans Trade in Lusaka, Zambia: A Trader's Perspective. SAR. 2016, Vol. 5, No. 2.

14. Cook, M. L.; Chaddad, F. R. Redesigning cooperative boundaries: the emergence of new models. Ame J Agric Econ. 2004, 86(5): 1249-1253.

15. Ortmann, G.F.; King, R.P. Agricultural cooperatives I\&II. Agrekon, 2007; 46, 1:40-68 \& 2: $219-244$

16. Oya, C. Contract Farming in Sub-Saharan Africa: A Survey of Approaches, Debates and Issues. J. Agrar. Chang, 2012, 12, 1-33.

17. AGRA. Africa Agriculture Status Report: The Business of Smallholder Agriculture in Sub Saharan Africa (Issue 5), Nairobi, Kenya: Alliance for a Green Revolution in Africa (AGRA). 2017

18. Krueger, R.A.; Casey, M.A. Focus Groups: A Practical Guide for Applied Research (3rd edn). Thousand Oaks, CA: Sage.2000

19. Chrisnall, P. Marketing Research. $7^{\text {th }}$ edition, McGraw Hill Education: New York, NY, USA. 2005

20. Shields, P.M.; Rangavajan, N.A. A playbook for Research Methods: Integrating conceptual frameworks and Project Management, New Forning Press: Stillwater, OK, USA. 2013

21. United States Agency for International Development. End Market Research Toolkit Upgrading Value Chain competitiveness With Informed Choice. 2008. (available at: https://beamexchange.org/uploads/filer_public/3f/5e/3f5ec4e0-4227-4ef6-8e8d039fe95cc01f/valuechainendmarkettoolkit.pdf)

22. Jaleta, M.; Gebremedhin, B.; Hoekstra, D. Smallholder commercialization:

Processes, determinants and impact. Discussion Paper No. 18. Improving Productivity and Market Success (IPMS) of Ethiopian Farmers Project, ILRI (International Livestock

Research Institute). Nairobi: ILRI. 2009. (Available at:

https://www.marketlinks.org/sites/marketlinks.org/files/resource/files/ILRI\%20-

$\%$ 20Smallholder\%20Commercialization\%20Processes.pdf)

23. Minot, N. Contract farming in Africa: Opportunities and challenges. Paper presented at AAMP Policy seminar on "Successful smallholder commercialization”, Kigali, Rwanda. 2011 
24. Dolan, C.; Humphrey, J. Changing governance patterns in the trade in Fresh vegetables between Africa and the United Kingdom. Environ. Plan. 2004, 36:491-509.

25. Tadele, Z. Raising Crop Productivity in Africa through Intensification. Agronomy, 2017, 7:22

26. Costales, A.; Catelo, M.A.O. Contract farming as an institution for integrating rural smallholders in markets for livestock products in developing countries: Results in case countries. Pro poor livestock policy initiative Research Report. 2009. (www.fao.org/3/abp264e.pdf).

27. Prowse, M. Contract farming in developing countries- A review. A Savoir No. 12, AFD

Research department, France. 2012. (Available at:

https://ign.ku.dk/english/employees/geography/?pure=files\%2F41824775\%2FProwse_20

12_Contract_farming_in_developing_countries_AFD_A_Savoir_Paper_12.pdf)

28. Taplin, D.H.; Clark, H.; Collins, E; Colby, D. Theory of change Technical Papers. ActKnowledge, New Yok. 2013.

29. Barret C.B. Smallholder market participation: Concepts and evidence from Eastern and Southern Africa. Food Policy 2008, 33:299-317.

30. Trienekens, J.A. Agricultural Value Chains in Developing Countries: A Framework for Analysis. IFAMR, 2011, Volume 14, issue 2.

31. Govereh, J.; Jayne, T. S.; Nyoro, J. Smallholder commercialization, interlinked markets and food crop productivity: Cross-country Evidence in Eastern and Southern Africa. 1999.

32. Government of Kenya. Kenya Vision 2030. Nairobi: Ministry of Planning. 2008.

33. United Nations. The Sustainable Development Goals Report. New York. 2016. 